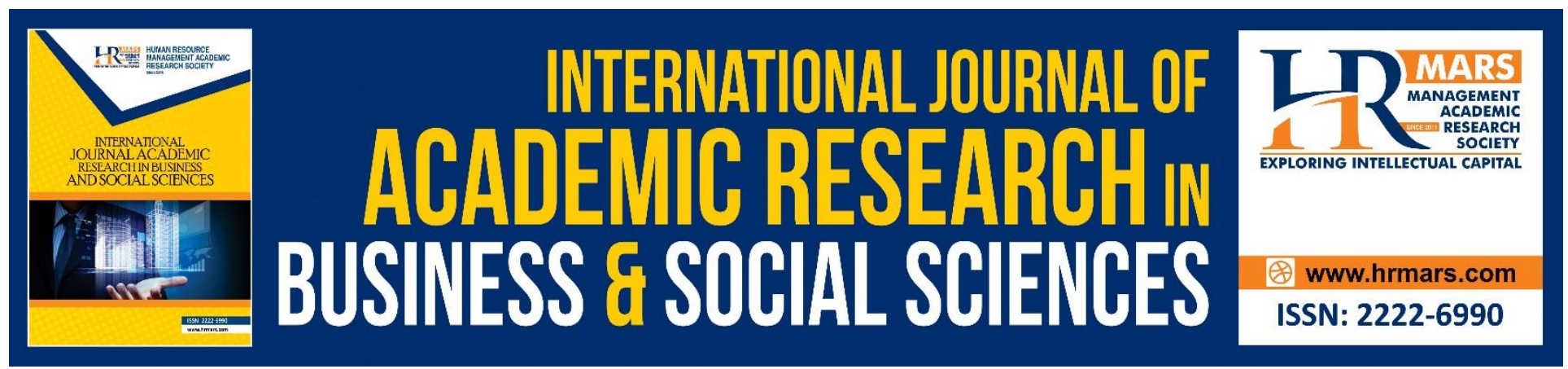

\title{
The Influence of Human Resource Development toward the Lecturers' Performance at the Faculty of Letters, University of Padjadjaran
}

Sedarmayanti, Sabar Gunawan, Ane Veriane, Metha Djuwita Supriatna, Mulyaningsih

To Link this Article: http://dx.doi.org/10.6007/IJARBSS/v11-i1/8472

DOI:10.6007/IJARBSS/v11-i1/8472

Received: 25 November 2020, Revised: 20 December 2020, Accepted: 04 January 2021

Published Online: 19 January 2021

In-Text Citation: (Sedarmayanti et al., 2021)

To Cite this Article: Sedarmayanti, Gunawan, S., Veriane, A., Supriatna, M. D., \& Mulyaningsih. (2021). The Influence of Human Resource Development toward the Lecturers' Performance at the Faculty of Letters, University of Padjadjaran. International Journal of Academic Research in Business and Social Sciences, 11(1), 261-275.

Copyright: (c) 2021 The Author(s)

Published by Human Resource Management Academic Research Society (www.hrmars.com)

This article is published under the Creative Commons Attribution (CC BY 4.0) license. Anyone may reproduce, distribute, translate and create derivative works of this article (for both commercial and non-commercial purposes), subject to full attribution to the original publication and authors. The full terms of this license may be seen

at: http://creativecommons.org/licences/by/4.0/legalcode

\section{Vol. 11, No. 1, 2021, Pg. 261 - 275}

Full Terms \& Conditions of access and use can be found at http://hrmars.com/index.php/pages/detail/publication-ethics 


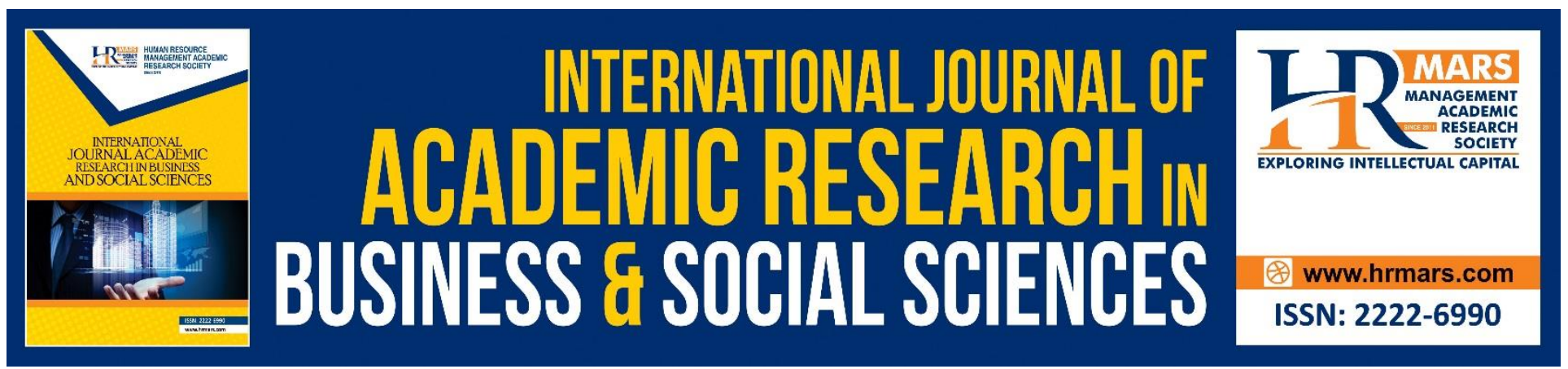

\title{
The Influence of Human Resource Development toward the Lecturers' Performance at the Faculty of Letters, University of Padjadjaran
}

\section{Sedarmayanti ${ }^{1}$, Sabar Gunawan², Ane Veriane ${ }^{3}$, Metha Djuwita Supriatna ${ }^{4}$, Mulyaningsih $^{5}$}

1) Professor, Faculty of Administrative Science-Dr Soetomo University Surabaya - Indonesia and School of Administration, National Agency for State Administration, Bandung, West Java, Indonesia

${ }^{2,4)}$ Lecturer, School of Administration, National Agency for State Administration, Bandung, West Java, Indonesia, ${ }^{3)}$ Student, Masters Degree Program, School of Administration Bandung, West Java, Indonesia, ${ }^{5)}$ Lecturer, Garut University, Indonesia

Email: sedarmayanti@gmail.com

\begin{abstract}
The purpose of this study is to determine determine the the influence of human resource development towards the Lecturers performance at the Faculty of Letters, University of Padjadjaran. The basic theory used as guidelines in this study, is the concept of human resource development. Human resource development referred in this research includes continuous professional development and maintenance of human resources. The method used in this research is quantitative approach. Meanwhile, primary data is obtained through a questionnaire, and there were 141 respondents who participated in the study. With an $\mathrm{R}$ square value of 0.840 , it means that continuous professional development and maintenance of human resources can affect lecturer performance by $84 \%$, together. The result of t-test showed that $t$-value is 5.753 with the sign $p$-value of 0.000 . Since the sign value $p$-value $(0.000)<0.05$ then the $\mathrm{Ho}$ is rejected. This means that human development variables significantly influence the performance of a lecturer at the Faculty of Letters, University of Padjadjaran.
\end{abstract}

Keywords: Human Resources Development, Continuous Professional Development, Maintenance of Human Resources, Performance, Lecturer.

\section{Introduction}

Higher education is one of the institutions expected to be able to prepare human resources in facing various challenges in order to be able to compete with other nations in the world. Therefore, universities are demanded to always be able to face and prepare various changes that occur, both from within the organization and from outside their organizations so that they can contribute constructively to the nation. One example of changes or challenges from outside the organization 
that are closely related to higher education is globalization in the field of education or so-called cross border education (especially higher education) which is applied by developed countries where higher education is used as a trade service (Knight, 2006) and it was ratified in the General Assessment on Trade in Service (GATS). Then another challenge is globalization at the ASEAN level, namely the MEA (ASEAN Economic Community) which is currently being rolled out. Both challenges, both directly and indirectly, have an impact on the competitive climate for all higher education institutions throughout the world, including in Indonesia. The expected role of academics in building the nation and facing global challenges is how they are able to contribute in increasing the nation's competitiveness and provide various research results that can be implemented for the community. Therefore, the Ministry of Research, Technology \& Higher Education has launched 50 state universities throughout Indonesia targeted to enter the category of world class universities in order to prepare organizations in the tertiary education environment to be able to compete, both regionally and globally. The next challenge is the establishment of several state universities to become legal entity colleges, one of which is Universitas Padjadjaran (Unpad).

Changes in leadership within the internal Unpad, of course also affect the change in several policies in it. The Chancellor chosen applies the main policy direction and Unpad transformative triangle. The transpormative triangle, among others is transforming academic processes oriented to the benefits of sustainable development, realizing transdisciplinary academic excellence through mainstreaming research and optimizing regional potentials in a global context, Unpad must be able to build resource independence through increased partnerships, with the spirit of "from West Java to the World through sustainable development" in order to realize SIAP academic corporate governance, namely synergy, integrity, accountability, and productivity. These changes have become a challenge for Unpad. Therefore Unpad seeks to organize and improve the internal conditions of the organization. In facing various changes, Unpad optimized collaboration with all faculties that are incorporated in it. The role of the faculty is very important in supporting university performance, because it is within the faculty, the process of organizational activities dynamically taking place, such as at the Faculty of Letters.

The Faculty of Letters, in particular, seeks to exploit the potential of its human resources, namely lecturers and staff to sustain the achievement of the organization's vision, mission and goals, through various development and maintenance programs for human resources that are expected to stimulate optimal performance. Arwidayanto (2012) explained that the challenge for higher education in managing human resources is to present professional lecturers so that they can produce competent graduates in accordance with their fields, and determine the quality of the college itself. So, in principle, human resource management in tertiary institutions is the management of human resources in the university environment, in order to prepare lecturers to face various challenges and changes that occur, uphold professionalism in shaping the quality of graduates in higher education and autonomy. One of them, by doing human resource development.

Human resource development is a process of increasing the ability of individuals in an organization, both for the long and short term, through education, training and development programs that can increase the abilities of individuals who can support the organization in achieving common goals (Armstrong, 2006). In relation to the world of higher education, especially for teaching staff or lecturers, it is hoped that they will contribute to the process of increasing the ability of lecturers through education and training as well as other development programs that encourage the creation of a better quality of life for the lecturer concerned and for the surrounding community. 
INTERNATIONAL JOURNAL OF ACADEMIC RESEARCH IN BUSINESS AND SOCIAL SCIENCES Vol. 11, No. 1, 2021, E-ISSN: 2222-6990 @ 2021 HRMARS

Human resource development is beneficial for an organization, especially in terms of achieving optimal organizational performance. In tertiary institutions, the development of lecturers and staff appears to be a real need for efforts to improve the quality of human resources through a systematic, coherent, measured and organized process. Such efforts must be presented in the management of higher education human resources that are able to meet the expectations of stakeholders (Arwidayanto, 2012).

Chikari et al., (2015) believes that continuous professional development is one way for professionals to improve competence through various programs, including through the process of education, training, learning and other supporting activities. Education is a process of developing knowledge, values and understanding needed in all aspects of life in addition to knowledge and skills related to certain fields of activity (Amstrong \& Taylor, 2014). Education for lecturers is an absolute prerequisite that must be met. The minimum education requirement for a lecturer is a master's degree, so if the lecturer does not meet the minimum standard, he is obliged to continue his studies to the master program. Education for lecturers is aimed at increasing competence in supporting the performance concerned, especially in the context of education and teaching. However, based on the results of observations, it can be seen that there are still four lecturers in the four study programs with undergraduate degrees. Referring to UU no. 12 of 2012, undergraduate programs are required to have lecturers with a minimum academic qualification of graduates from a master's program or equivalent. Based on these regulations, there are problems in the field of lecturer education. Training is necessary for lecturers in terms of improving technical skills to fulfill their teaching, research and community service obligations. Training is an inseparable need in increasing the professionalism of lecturers, so that lecturers are expected to be able to transfer knowledge to students guided by provision of good character building for students when they go into society. Regarding training, it can be seen that the planned training programs have not been fully implemented, where only $56 \%$ of all activities have been implemented. Finally, supporting activities are activities carried out in order to support activities in fields related to education or other supporting activities that can be useful for the benefit of the community. Based on the results of preliminary observations, it can be seen that of the twenty-six supporting activities planned, only ten activities have been achieved, but sixteen have not been realized.

Besides being developed, human resources also need to be maintained. The maintenance of human resources is an action taken by an organization in order to maintain its human resources so that they can always work optimally without neglecting the interests and needs of each human resource (Beheshfiar, Malikeh \& Safarian, 2013; Beheshtifar, Malikeh \& Asadi, 2013). The purpose of maintaining human resources is to increase productivity, discipline, loyalty, work motivation, security, comfort, a harmonious atmosphere, reduce boredom, all of these goals are basically in order to improve organizational performance. The maintenance of human resources can be carried out by planning safety design, medical care, and welfare services (Beheshtifar, Malikeh \& Asadi, 2013). Safety design planning deals with actions in order to avoid accidents in the workplace, by means of the organization preparing anticipatory steps in order to reduce accidents in the workplace. If the organization takes precautions in the workplace, this can minimize accidents and provide comfort in the workplace. Medical treatment measures are actions taken in order to support staff in the process of healing from a disease, this support can be in the form of assistance with health costs or better environmental conditions. With this medical treatment action, it can actually be used as a reference in order to see how far the organization cares for its employees by helping employees in the healing 
INTERNATIONAL JOURNAL OF ACADEMIC RESEARCH IN BUSINESS AND SOCIAL SCIENCES Vol. 11, No. 1, 2021, E-ISSN: 2222-6990 @ 2021 HRMARS

process and creating a better working environment or conditions. the welfare service program aims to meet the various needs of employees who will come on an ongoing basis. The main benefits of the employee welfare program include increasing morale. Service activities for employees include: recreational programs; cafeteria; housing; educational scholarships; consultation and various other services. Thus employees can always work in a conducive atmosphere and this will have an impact on the overall performance of the organization.

Therefore, the performance of lecturers and education personnel need to be considered and is constantly being improved to support the performance of the faculty. Performance is the result of a person's work (output) in an organization both in quality and quantity and is carried out with full responsibility for supporting the management of the location of the organization's goals (PB, 2010; Wibowo, 2013). The main task of a lecturer is to carry out the tridharma of higher education, covering education and teaching, research and community service with a workload of at least 12 credits and a maximum of 16 credits in each semester. In measuring the performance of lecturers, it refers to the tridharma of higher education, namely educational and teaching activities carried out by lecturers, the participation of lecturers in research and community service, in addition to other supporting activities that support the tridharma of higher education. related to the performance of lecturers, several phenomena are found as follows: 1 ) The teaching sector has decreased from 2013-2014, from $78.00 \%$ to $77.00 \%$, then in 2015 it rose to $77.10 \%$. Based on these data, it can be seen that there are several obstacles in the teaching field, including: lectures, mentoring, testing thesis / dissertation sessions and dissertations, modules and teaching materials, preparing literature independently. Besides that, in the field of education and teaching, the teaching of lecturers is still not optimal, among others, there are still some lecturers who did not submit SAP at the beginning of the lecture, some lecturers as guardian lecturers did not motivate their guidance students, there were still some lecturers who were reluctant to give supplementary exams to students whose reasons are quite strong, 2) Research activity is seen a decrease in percentage in the field of research from $73.50 \%$ in 2013 to $70.50 \%$ in 2014 and decreased again in 2015 to 70.15 . From the data it can be seen that there is a decrease in the interest of lecturers in the field of research. 3) Community activity is seen a decrease in the percentage of the field of community service, in 2013 by $79.00 \%$ to $78.95 \%$ in 2014 and increased again to $79.05 \%$ in 2015 . It seems that there is a tendency for the achievement of lecturers' performance in the field of community service to increase despite the small percentage. However, based on observations made by the author that not all lecturers from each study program can play an active role in community service activities because there are various technical obstacles found in the field.

The role of lecturers as scholars is expected to contribute to each stage of development, transforming and contributing ideas, knowledge and research results not only to students but also to the community. In connection with the importance of the position of lecturers in the community, the organization is expected to be able to optimize its role in developing the scientific field it occupies, so as to stimulate the achievement of lecturer performance in accordance with what is expected by the organization. However, often in the process found several obstacles that were feared could hamper the achievement of the lecturer's performance. Based on these phenomena and problems, the authors suspect that the performance of lecturers at the Faculty of Letters Sciences Unpad is not optimal in relation to continuous professional development and maintenance at the Faculty of Letters Sciences Unpad. 
INTERNATIONAL JOURNAL OF ACADEMIC RESEARCH IN BUSINESS AND SOCIAL SCIENCES Vol. 11, No. 1, 2021, E-ISSN: 2222-6990 @ 2021 HRMARS

\section{Research Purpose and Problem}

In essence, human resource development aims to improve the performance of the workers themselves and encourage organizations to gain optimal excellence. At the Faculty of Letters Sciences Unpad, based on the results of observations that have been made, several problems are still found related to the performance of the lecturers, including: 1 ) There are lecturers who have undergraduate education. Refer to Law No. 12 of 2012, that undergraduate programs are required to have lecturers who have academic qualifications of at least a graduate of a master's program or equivalent. Based on these regulations, it appears that there are problems in the field of education of lecturers with a Bachelor's degree must immediately adjust to applicable regulations, 2) Some training activities are still not fully achieved, and 3) planned supporting activities still have not been implemented. Implementation in human resource development can be carried out by carrying out continuous professional development and maintenance of human resources. (Chikari et al., 2015) explained that the professional development process consists of education, training, learning, and supporting activities. Meanwhile, Syedjavadin in Beheshfiar, Malikeh \& Safarian (2013) explained that the maintenance of human resources can be done by planning safety designs, providing medical care, and providing health services. Regarding to the problems mentioned above, the purposes of this study are as follows:

1. Describe the application of continuous professional application and maintenance for lecturers at the Faculty of Letters Unpad.

2. Determine the effect of continuous professional development and maintenance of human resources on the performance of lecturers at the Faculty of Letters, Padjadjaran University.

\section{Method}

The research method used in this research is quantitative research methods. The population in this study is 141 lecturers at the Faculty of Letters. Primary data are obtained directly from units at the Faculty of Letters using a questionnaire. The questionnaire consists of 71 statement items, with details of 20 questions regarding continuous professional development, 21 questions regarding human resource maintenance and 30 items regarding lecturer performance. Data analysis activities are activities in the context of processing data that has been processed using certain statistical techniques. This was done with the aim of obtaining answers to the subject matter of the study and testing the hypotheses that had been formulated previously. Data from the research results that have been obtained, given a score or value, to determine the response of respondents to each indicator variable, so it can know the description of the respondent's response, what percentage. This can be used as a measurement of descriptive analysis. This study uses Quantitative method with multiple regression approach to examine the effect of continuous professional development and maintenance of human resources on the performance of lecturers at the Faculty of Letters, Padjadjaran University.

\section{Results}

The validity and reliability of the questionnaire examined before the research data is analyzed. The validity test is carried out to determine whether the measuring instrument arranged in the form of a questionnaire can actually carry out its measuring function. 
INTERNATIONAL JOURNAL OF ACADEMIC RESEARCH IN BUSINESS AND SOCIAL SCIENCES

Vol. 11, No. 1, 2021, E-ISSN: 2222-6990 @ 2021 HRMARS

Tabel 1. Validity Test Results

\begin{tabular}{|c|c|c|c|c|c|c|c|c|c|c|c|}
\hline \multicolumn{4}{|c|}{$\begin{array}{c}\text { Continuous Professional } \\
\text { Development (X1) }\end{array}$} & \multicolumn{4}{|c|}{ Human Resource Maintenance (X2) } & \multicolumn{4}{|c|}{ Performance $(\mathrm{Y})$} \\
\hline Item & $\begin{array}{c}r \\
\text { count }\end{array}$ & $\begin{array}{c}r \\
\text { critical }\end{array}$ & Information & item & $\begin{array}{c}r \\
\text { count }\end{array}$ & $\begin{array}{c}r \\
\text { critical }\end{array}$ & Information & Item & $\begin{array}{c}r \\
\text { count }\end{array}$ & $\begin{array}{c}r \\
\text { critical }\end{array}$ & Information \\
\hline 1 & 0.800 & 0.30 & Valid & 1 & 0.772 & 0.30 & Valid & 1 & 0.733 & 0.30 & Valid \\
\hline 2 & 0.799 & 0.30 & Valid & 2 & 0.829 & 0.30 & Valid & 2 & 0.829 & 0.30 & Valid \\
\hline 3 & 0.793 & 0.30 & Valid & 3 & 0.815 & 0.30 & Valid & 3 & 0.808 & 0.30 & Valid \\
\hline 4 & 0.816 & 0.30 & Valid & 4 & 0.819 & 0.30 & Valid & 4 & 0.820 & 0.30 & Valid \\
\hline 5 & 0.854 & 0.30 & Valid & 5 & 0.811 & 0.30 & Valid & 5 & 0.834 & 0.30 & Valid \\
\hline 6 & 0.801 & 0.30 & Valid & 6 & 0.829 & 0.30 & Valid & 6 & 0.808 & 0.30 & Valid \\
\hline 7 & 0.847 & 0.30 & Valid & 7 & 0.828 & 0.30 & Valid & 7 & 0.812 & 0.30 & Valid \\
\hline 8 & 0.837 & 0.30 & Valid & 8 & 0.797 & 0.30 & Valid & 8 & 0.764 & 0.30 & Valid \\
\hline 9 & 0.850 & 0.30 & Valid & 9 & 0.818 & 0.30 & Valid & 9 & 0.820 & 0.30 & Valid \\
\hline 10 & 0.797 & 0.30 & Valid & 10 & 0.810 & 0.30 & Valid & 10 & 0.821 & 0.30 & Valid \\
\hline 11 & 0.830 & 0.30 & Valid & 11 & 0.809 & 0.30 & Valid & 11 & 0.820 & 0.30 & Valid \\
\hline 12 & 0.825 & 0.30 & Valid & 12 & 0.815 & 0.30 & Valid & 12 & 0.824 & 0.30 & Valid \\
\hline 13 & 0.839 & 0.30 & Valid & 13 & 0.789 & 0.30 & Valid & 13 & 0.814 & 0.30 & Valid \\
\hline 14 & 0.798 & 0.30 & Valid & 14 & 0.851 & 0.30 & Valid & 14 & 0.842 & 0.30 & Valid \\
\hline 15 & 0.859 & 0.30 & Valid & 15 & 0.822 & 0.30 & Valid & 15 & 0.832 & 0.30 & Valid \\
\hline 16 & 0.848 & 0.30 & Valid & 16 & 0.827 & 0.30 & Valid & 16 & 0.851 & 0.30 & Valid \\
\hline 17 & 0.826 & 0.30 & Valid & 17 & 0.805 & 0.30 & Valid & 17 & 0.844 & 0.30 & Valid \\
\hline 18 & 0.831 & 0.30 & Valid & 18 & 0.830 & 0.30 & Valid & 18 & 0.810 & 0.30 & Valid \\
\hline 19 & 0.826 & 0.30 & Valid & 19 & 0.798 & 0.30 & Valid & 19 & 0.831 & 0.30 & Valid \\
\hline \multirow[t]{11}{*}{20} & \multirow[t]{11}{*}{0.844} & \multirow[t]{11}{*}{0.30} & \multirow[t]{11}{*}{ Valid } & 20 & 0.828 & 0.30 & Valid & 20 & 0.807 & 0.30 & Valid \\
\hline & & & & \multirow[t]{10}{*}{21} & \multirow[t]{10}{*}{0.760} & \multirow[t]{10}{*}{0.30} & \multirow[t]{10}{*}{ Valid } & 21 & 0.787 & 0.30 & Valid \\
\hline & & & & & & & & 22 & 0.839 & 0.30 & Valid \\
\hline & & & & & & & & 23 & 0.844 & 0.30 & Valid \\
\hline & & & & & & & & 24 & 0.832 & 0.30 & Valid \\
\hline & & & & & & & & 25 & 0.838 & 0.30 & Valid \\
\hline & & & & & & & & 26 & 0.836 & 0.30 & Valid \\
\hline & & & & & & & & 27 & 0.810 & 0.30 & Valid \\
\hline & & & & & & & & 28 & 0.836 & 0.30 & Valid \\
\hline & & & & & & & & 29 & 0.778 & 0.30 & Valid \\
\hline & & & & & & & & 30 & 0.809 & 0.30 & Valid \\
\hline
\end{tabular}

The validity test was carried out on the three variables, that is $X_{1}$ (continuous professional development), $X_{2}$ (human resource maintenance) and the $Y$ coefficient (lecturer performance) totaling 71 statements. The results show that all items tested were declared valid because they were above the critical value $(>0.3)$, and were worthy of use for further analysis. 
INTERNATIONAL JOURNAL OF ACADEMIC RESEARCH IN BUSINESS AND SOCIAL SCIENCES Vol. 11, No. 1, 2021, E-ISSN: 2222-6990 @ 2021 HRMARS

Tabel 2. Reliability Test Results

\begin{tabular}{|c|c|c|}
\hline & Cronbach's Alpha & $\mathrm{N}$ of items \\
\hline Professional & 0,975 & 20 \\
\hline \multicolumn{3}{|l|}{ Development (X1) } \\
\hline Human Resource Maintenance (X2) & 0,974 & 21 \\
\hline Performance (Y) & 0,983 & 30 \\
\hline
\end{tabular}

The instrument reliability test aims to determine whether the instrument used as a data collection tool is reliable or not or the reliability test can be used to show the standard level of a research instrument whether the instrument is reliable or not. From the table above, it can be seen that the alpha coefficient of variables $X_{1}, X_{2}$ and variable $Y$ is more than 0.7 , variable $X_{1}$ has an alpha coefficient of 0.975 , variable $X_{2}$ has an alpha coefficient of 0.974 , while for variable $Y$ the alpha coefficient is 0.983. From these calculations, it can be seen that all the instruments used in this study are reliable and can be used to measure the variables of human resource development and lecturer performance. Before the regression testing analysis is carried out, here we first describe the total score of respondents' responses to the research variables, namely variables continuous professional development, human resource maintenance, and performance.

Continuous professional development consists of 4 dimensions, namely education, training, learning, and supporting activities (Chikari et al., 2015). The results of respondents' responses to the four dimensions are presented in the table below.

Tabel 3. Respondent's Response to Variables Continuous Profession Development

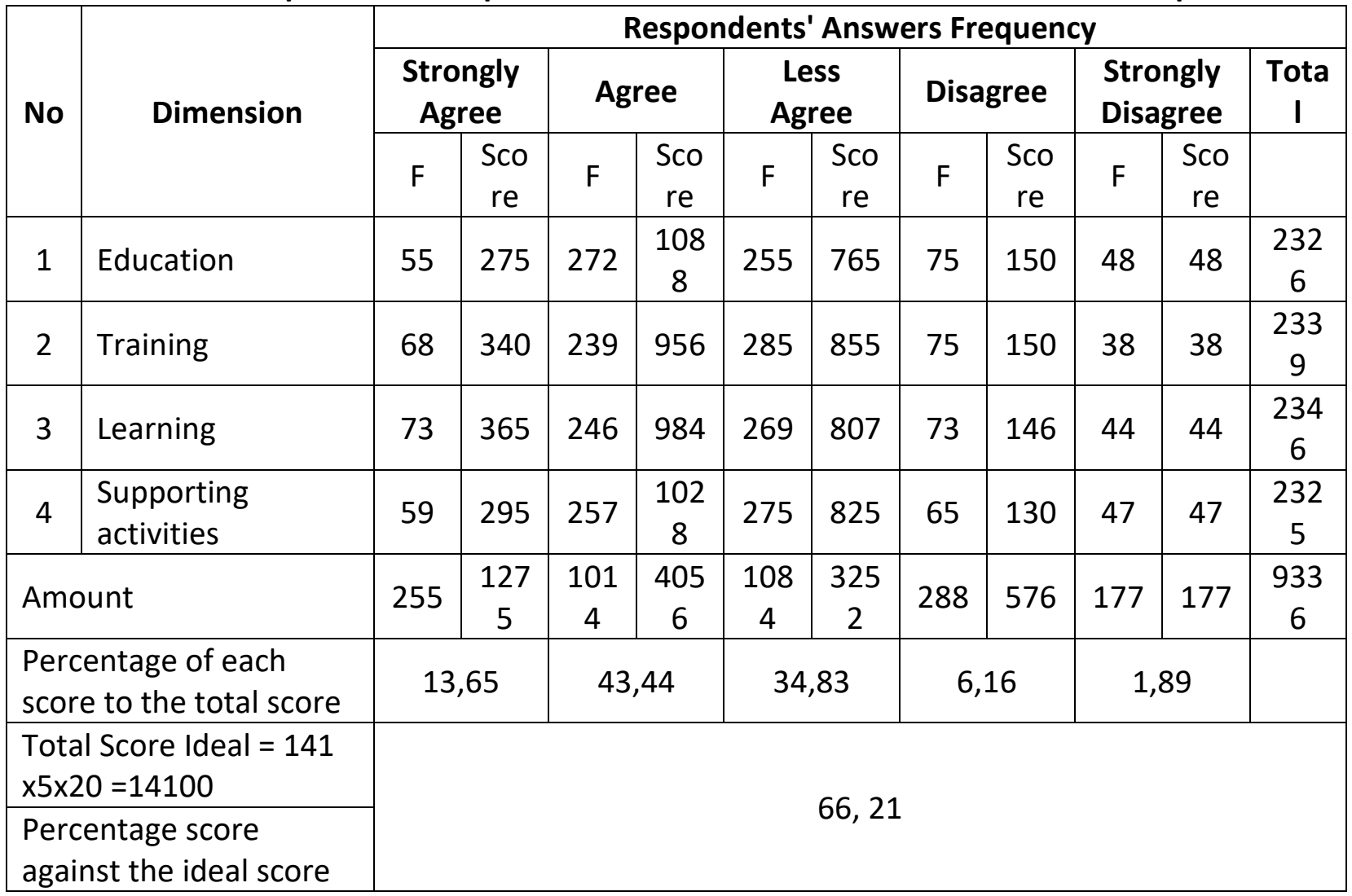


INTERNATIONAL JOURNAL OF ACADEMIC RESEARCH IN BUSINESS AND SOCIAL SCIENCES Vol. 11, No. 1, 2021, E-ISSN: 2222-6990 @ 2021 HRMARS

Human resource maintenance consists of three dimensions, that is safety design planning, medical care planning and welfare services. The results of respondents' responses to the three dimensions are presented in the table below.

Tabel 4. Recapitulation Of Respondent Response To HR Maintenance Variables

\begin{tabular}{|c|c|c|c|c|c|c|c|c|c|c|c|c|}
\hline \multirow{3}{*}{$\begin{array}{l}\mathbf{N} \\
\mathbf{0}\end{array}$} & \multirow{3}{*}{ Dimension } & \multicolumn{10}{|c|}{ Respondents' Answers Frequency } & \multirow{3}{*}{ Total } \\
\hline & & \multicolumn{2}{|c|}{$\begin{array}{l}\text { Strongly } \\
\text { Agree }\end{array}$} & \multicolumn{2}{|c|}{ Agree } & \multicolumn{2}{|c|}{$\begin{array}{l}\text { Less } \\
\text { Agree }\end{array}$} & \multicolumn{2}{|c|}{ Disagree } & \multicolumn{2}{|c|}{$\begin{array}{l}\text { Strongly } \\
\text { Disagree }\end{array}$} & \\
\hline & & $\mathrm{F}$ & $\begin{array}{l}\text { Sco } \\
\text { re }\end{array}$ & $\mathrm{F}$ & $\begin{array}{l}\text { Sco } \\
\text { re }\end{array}$ & $\mathrm{F}$ & $\begin{array}{l}\text { Sco } \\
\text { re }\end{array}$ & $\mathrm{F}$ & $\begin{array}{l}\text { Sco } \\
\text { re }\end{array}$ & $\mathrm{F}$ & $\begin{array}{l}\text { Sco } \\
\text { re }\end{array}$ & \\
\hline 1 & Safety Design & 97 & 485 & 351 & $\begin{array}{c}140 \\
4\end{array}$ & 365 & $\begin{array}{c}109 \\
5\end{array}$ & 106 & 212 & 68 & 68 & 3264 \\
\hline 2 & $\begin{array}{l}\text { Medical Treatment } \\
\text { Planning }\end{array}$ & 90 & 450 & 358 & $\begin{array}{c}143 \\
2 \\
\end{array}$ & 381 & $\begin{array}{c}114 \\
3\end{array}$ & 91 & 182 & 67 & 67 & 3274 \\
\hline 3 & Welfare Services & 91 & 455 & 365 & $\begin{array}{c}146 \\
0\end{array}$ & 375 & $\begin{array}{c}112 \\
5\end{array}$ & 98 & 196 & 58 & 58 & 3294 \\
\hline \multicolumn{2}{|c|}{ Amount } & 278 & $\begin{array}{c}139 \\
0 \\
\end{array}$ & $\begin{array}{c}107 \\
4 \\
\end{array}$ & $\begin{array}{c}429 \\
6 \\
\end{array}$ & $\begin{array}{c}112 \\
1 \\
\end{array}$ & $\begin{array}{c}336 \\
3 \\
\end{array}$ & 295 & 590 & 193 & 193 & 9832 \\
\hline \multicolumn{2}{|c|}{$\begin{array}{l}\text { Percentage of each score } \\
\text { to the total score }\end{array}$} & \multicolumn{2}{|c|}{14,13} & \multicolumn{2}{|c|}{43,69} & \multicolumn{2}{|c|}{34,20} & \multicolumn{2}{|c|}{6,00} & \multicolumn{2}{|c|}{1,92} & \\
\hline \multicolumn{2}{|c|}{$\begin{array}{l}\text { Total Score Ideal = } 141 \\
x 5 \times 21=14805\end{array}$} & \multirow{2}{*}{\multicolumn{11}{|c|}{66,40}} \\
\hline $\begin{array}{l}\text { Per } \\
\text { the }\end{array}$ & $\begin{array}{l}\text { centage score against } \\
\text { ideal score }\end{array}$ & & & & & & & & & & & \\
\hline
\end{tabular}

The description of lecturer performance at the Faculty of Letters Sciences Unpad will be seen through the answers from respondents to the statements submitted through questionnaires or questionnaires that cover 3 dimensions. Measurement of lecturer performance using these 3 dimensions, translated into 30 statement items which includes 3 dimensions, that is Organizing Education, Conducting Research, and Organizing Community Service. The results of respondents' responses to the three dimensions are presented in the table below. 
INTERNATIONAL JOURNAL OF ACADEMIC RESEARCH IN BUSINESS AND SOCIAL SCIENCES Vol. 11, No. 1, 2021, E-ISSN: 2222-6990 @ 2021 HRMARS

Tabel 5. Respondent's Response To Performance Variables Of Lecturers

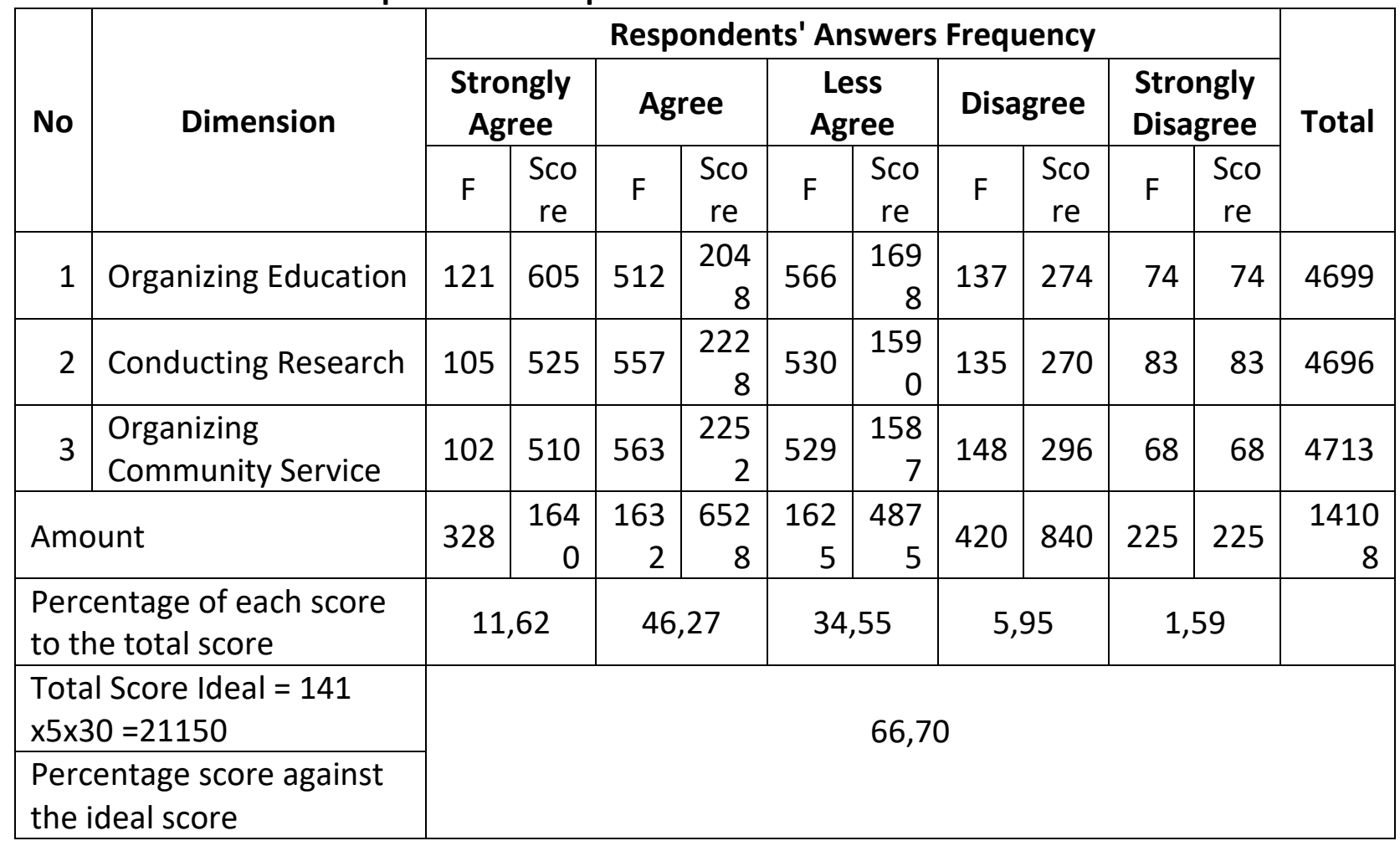

Based on the research objectives to be achieved, namely to prove whether there is an effect of continuous professional development and maintenance on the performance (human resources development) of lecturers at the Faculty of Letters Sciences Unpad, multiple linear regression analysis tests were carried out.

Tabel 6. The results of multiple linear regression analysis

\begin{tabular}{|c|c|c|c|c|}
\hline & \multicolumn{2}{|c|}{$\begin{array}{c}\text { Unstandardized } \\
\text { Coefficients }\end{array}$} & \multirow[t]{2}{*}{$\mathrm{t}$} & \multirow[t]{2}{*}{ Sig. } \\
\hline & $\mathrm{B}$ & Std. Error & & \\
\hline (Constant) & 5.308 & 3.324 & 1.597 & .113 \\
\hline Continuous Profession Development $\left(\mathrm{X}_{1}\right)$ & .459 & .078 & 5.858 & .000 \\
\hline HR Maintenance $\left(X_{2}\right)$ & .948 & .075 & 12.594 & .000 \\
\hline
\end{tabular}

The regression coefficient for the continuous professional development variable is 0.459 which indicates the magnitude of the change in the average performance score of lecturers which is influenced by continuous professional development. The positive sign indicates that the effect is unidirectional, meaning that every time there is an increase in the score for the continuous professional development variable by 1 unit and the other variables are considered constant, the lecturer performance is predicted to increase by 0.459 units. The regression coefficient for the maintenance variable is 0.948 which indicates the change in the average score of lecturer performance which is influenced by maintenance, a positive sign indicates that the effect is 
INTERNATIONAL JOURNAL OF ACADEMIC RESEARCH IN BUSINESS AND SOCIAL SCIENCES Vol. 11, No. 1, 2021, E-ISSN: 2222-6990 @ 2021 HRMARS

unidirectional, meaning that every increase in the maintenance variable is 1 unit and other variables are considered constant, then lecturer performance is predicted to increase by 0.948 units. The coefficient of determination of 0.840 indicates that Continuous Professional Development and maintenance provides $84 \%$ diversity to Lecturer Performance. While the remaining $16 \%$ is influenced by other factors not observed in this study.

Tabel 7. Determination Coefficient Value

\begin{tabular}{|l|l|r|r|r|r|}
\hline Model & $\mathrm{R}$ & R Square & $\begin{array}{c}\text { Adjusted R } \\
\text { Square }\end{array}$ & $\begin{array}{c}\text { Std. Error of } \\
\text { the Estimate }\end{array}$ & $\begin{array}{c}\text { Durbin- } \\
\text { Watson }\end{array}$ \\
\hline 1 & $.917^{\mathrm{a}}$ & .840 & .838 & 9.18016 & 2.076 \\
\hline
\end{tabular}

The result of t-test showed that $t$-value is 5.753 with the sign $p$-value of 0.000 . Since the sign value $p$-value $(0.000)<0.05$ then the $\mathrm{Ho}$ is rejected. This means that human development variables significantly influence the performance of a lecturer at the Faculty of Letters, University of Padjadjaran.

\section{Discussion}

Continuous professional development consists of 4 dimensions, namely education, training, learning, and supporting activities. The dimension of education is measured by using 5 statement items regarding the educational standards of the lecturers, the status of the lecturers in education, organizational support for studies and scholarships. The dimension of education is measured by using 5 statement items concerning the educational standards of the lecturers, the status of the lecturers in education, organizational support for studies and scholarships. The education dimension has a score percentage of $65.98 \%$. This shows that the implementation of continuous professional development for the educational aspect is in a fairly good category. Then it can be seen that most of the lecturers have met the educational standards set by DIKTI, only a small portion still do not meet the standards. Then the lecturer status is given the opportunity to attend school and is given adequate scholarships to continue their studies. Regarding organizational support for lecturers who wish to continue their studies, most respondents answered agree that the Faculty of Letters Sciences Unpad supports lecturers to continue their studies to a higher level. Then regarding support in terms of lecturers receiving scholarships, the most respondents answered agree and disagree. Based on the results of this categorization, the total score of respondents' responses to the five questions was 2326, indicating that the respondent's level of response to the five statements submitted about education was in the quite good category. From this data, it reflects that the opportunity for lecturers to continue their education at the Faculty of Letters Sciences Unpad is good. The training dimension is measured by using 5 statement items, concerning training activities that support lecturer performance, participation in training and training continuity. The implementation of human resource development at the Faculty of Letters, Padjadjaran University, especially lecturers for training indicators has a score percentage of $66.35 \%$, which is included in the fairly good category. This shows that the implementation of human resource development for the training aspect is in a fairly good category. The learning dimension is measured by using 5 statement items, concerning learning activities that support lecturer performance. The implementation of continuous professional development at the Faculty of Letters, Padjadjaran University, especially lecturers for learning indicators has a score percentage of $66.55 \%$, which falls into the fairly good category. This shows that 
INTERNATIONAL JOURNAL OF ACADEMIC RESEARCH IN BUSINESS AND SOCIAL SCIENCES Vol. 11, No. 1, 2021, E-ISSN: 2222-6990 @ 2021 HRMARS

the implementation of human resource development for the learning aspects is in a fairly good category. The development dimension is measured by using 5 statement items regarding supporting activities. The implementation of continuous professional development at the Faculty of Letters Sciences Unpad, especially lecturers for indicators of supporting activities, has a score percentage of $65.95 \%$. This shows that the implementation of continuous professional development for the aspects of supporting activities is in a fairly good category. Based on table 3, continuous professional development has a score percentage of $66.21 \%$. It shows that the implementation of the continuous profession is in a fairly good category. That is, professional development carried out by lecturers in order to improve skills and competencies that are useful for their role as educators to improve knowledge and insights that are useful for the surrounding environment through education, training, learning, and participating in supporting activities is considered quite good. The greatest total score is for the learning dimension, where the learning activities held for lecturers include the Academic Recharging Program (PAR), the Sandwich Program, Soft Skills Development, and Visitting Lecturers. While the smallest total score is for the dimension of supporting activities, where the supporting activities carried out include workshops, national seminars, conferences, and guest lecturer programs. Therefore, it is necessary to encourage lecturers to be active in carrying out activities.

HR Maintenance consists of three dimensions, including safety design planning, medical care planning and welfare services. The dimensions of work safety design planning are measured using 7 statement items that support lecturer performance. The safety design planning dimension has a score percentage of $65.58 \%$, this shows that the implementation of human resource maintenance for aspects of safety design planning activities is in a fairly good category. The dimensions of welfare service planning are measured using 7 statement items that support lecturer performance. Human resource maintenance services at the Faculty of Letters, Padjadjaran University, especially lecturers for welfare service indicators have a percentage score of $66.74 \%$. This shows that the implementation of maintenance of human resources for aspects of welfare services is in a fairly good category. Based on table 4 , the average total score for the HR maintenance variable is $66.40 \%$, and it is in the quite good category. That is, efforts to foster and develop the physical, mental, attitude and behavior of employees so that employees become loyal and able to work optimally are considered sufficient in accordance with the needs of the company. The highest total score is for the welfare service dimension, this is because the faculty routinely conducts recreational activities for the lecturers. While the lowest value is for the dimension of safety design planning. This is because the faculty has provided facilities and infrastructure that are classified as sufficient to ensure the safety of its workers, so that workers feel comfortable doing their activities in the office.

The description of lecturer performance at the Faculty of Letters Sciences Unpad is seen from how the lecturers carry out education and teaching, research, and community service. The indicator of organizing education and teaching has a score percentage of $66.65 \%$. This shows that the performance of lecturers at the Faculty of Letters Sciences Unpad in the aspect of organizing education and teaching is in a fairly good category. The indicator of conducting research has a score percentage of $66.60 \%$, this shows that the performance of lecturers at the Faculty of Letters Sciences Unpad for the aspect of conducting research is in a fairly good category. The indicator of carrying out community service has a percentage score of $66.85 \%$. This shows that the performance of lecturers at the Faculty of Letters Sciences Unpad for the aspect of organizing community service is in a fairly good category. In order to know how the lecturers' performance of the Faculty of Letters Sciences Unpad as a whole, the authors categorized the recapitulation of the total score of respondents on 
the three dimensions of lecturer performance. Based on table 5, the total response score for performance variable has a percentage score of $66.70 \%$, and in the quite good category. The highest score is for the dimension of doing community service. This means that lecturers have been actively carrying out activities related to community service. The lowest total score is for the dimension of conducting research. This means that the activities of conducting research conducted by lecturers are in the sufficient category. This can be improved by encouraging the lecturers to carry out research activities, besides the application of rewards and punishments will encourage lecturers' activeness in conducting research.

Before performing multiple linear regression analysis, there are several assumptions that must be fulfilled, namely the Normality Test, Multicollinearity Test, Heteroscedasticity Test and Autocorrelation Test. The results show that there is no autocorrelation in the research model. Thus, there is no strong relationship between residuals in the research model. Based on Tabel 6 \& 7, a constant of 5.308 indicates the average lecturer's performance score if the score for continuous professional development and maintenance is zero. The regression coefficient for the continuous professional development variable $\left(\mathrm{X}_{1}\right)$ is 0.459 which indicates the amount of change in the mean change in lecturer performance scores that is influenced by continuous professional development. The positive sign indicates that the effect is unidirectional, meaning that every time there is an increase in the score for the continuous professional development variable by 1 unit and the other variables are considered constant, the lecturer performance is predicted to increase by 0.459 units. Based on this calculation, it can be concluded that continuous professional development has an effect on lecturer performance. The regression coefficient for the maintenance variable $\left(X_{2}\right)$ is 0.948 which shows the amount of change in the average performance score of lecturers which is influenced by maintenance, a positive sign indicates that the effect is unidirectional, meaning that every increase in the maintenance variable is 1 unit and other variables are considered constant, then lecturer performance is predicted to increase by 0.948 units. This means that by encouraging activities related to continuous professional development for lecturers, as well as maintaining human resources, can encourage the improvement of the lecturer's own performance. This means that by encouraging activities related to continuous professional development for lecturers, as well as maintaining human resources, can encourage the improvement of the lecturer's own performance. It is important for universities to continue to improve the competence of their lecturers through education, providing training, conducting learning activities, and encouraging lecturers to actively participate in carrying out supporting activities, such as attending seminars or conferences. Making lecturers comfortable to be in the office environment will also encourage the performance of the lecturers. The provision of facilities and infrastructure as well as a conducive layout for lecturers to work will make the lecturer comfortable and enthusiastic about carrying out his work activities.

Based on the calculation of the regression coefficient, it can be concluded that the maintenance of human resources has an effect on lecturer performance. The coefficient of determination of 0.840 indicates that Continuous Professional Development and HR maintenance provides $84 \%$ diversity to Lecturer Performance. While the remaining $16 \%$ is influenced by other factors not observed in this study. The result of t-test showed that $t$-value is 5.753 with the sign $p$-value of 0.000 . Since the sign value $p$-value $(0.000)<0.05$ then the $\mathrm{Ho}$ is rejected. This means Continuous Professional Development and HR maintenance significantly influence the performance of a lecturer at the Faculty of Letters, University of Padjadjaran. This means that the more routine continuous professional development activities for lecturers, by being provided with education, training, learning, and 
INTERNATIONAL JOURNAL OF ACADEMIC RESEARCH IN BUSINESS AND SOCIAL SCIENCES Vol. 11, No. 1, 2021, E-ISSN: 2222-6990 @ 2021 HRMARS

implementing supporting activities, as well as ensuring that the HR maintenance process is going well, will improve the performance of the lecturer.

\section{Conclusions}

Continuous Professional Development is included in the fairly good score category, this proportion is obtained from the dimensions of education, training, learning and supporting activities. That is, professional development carried out by lecturers in order to improve skills and competencies that are useful for their role as educators to improve knowledge and insights that are useful for the surrounding environment through education, training, learning, and participating in supporting activities is considered quite good. The greatest total score is for the learning dimension, where the learning activities held for lecturers include the Academic Recharging Program (PAR), the Sandwich Program, Soft Skills Development, and Visitting Lecturers. While the smallest total score is for the dimension of supporting activities, where the supporting activities carried out include workshops, national seminars, conferences, and guest lecturer programs. Therefore, it is necessary to encourage lecturers to be active in carrying out activities. While HR maintenance is included in the fairly good category, this value is obtained from the dimensions of work safety planning, dimensions of medical service planning, and welfare services. That is, efforts to foster and develop the physical, mental, attitude and behavior of employees so that employees become loyal and able to work optimally are considered sufficient in accordance with the needs of the company. The highest total score is for the welfare service dimension, this is because the faculty routinely conducts recreational activities for the lecturers. While the lowest value is for the dimension of safety design planning. This is because the faculty has provided facilities and infrastructure that are classified as sufficient to ensure the safety of its workers, so that workers feel comfortable doing their activities in the office. The lecturer's performance is in the quite good category. The highest score is for the dimension of doing community service. This means that lecturers have been actively carrying out activities related to community service. The lowest total score is for the dimension of conducting research. This means that the activities of conducting research conducted by lecturers are in the sufficient category. This can be improved by encouraging the lecturers to carry out research activities, besides the application of rewards and punishments will encourage lecturers' activeness in conducting research. The results of the regression analysis show that the Continuous Professional Development and HR maintenance variables significantly influence the performance of a lecturer at the Faculty of Letters, University of Padjadjaran. This means that the more routine continuous professional development activities for lecturers, by being provided with education, training, learning, and implementing supporting activities, as well as ensuring that the HR maintenance process is going well, will improve the performance of the lecturer.

\section{References}

Amstrong, M., \& Taylor, S. (2014). A Handbook of Human Resource Management Practise 14th Edition. Kogan Page.

Armstrong, M. (2006). A Handbook of Human Resource Management Practice. Cambridge University Press.

Arwidayanto. (2012). Manajemen Sumber Daya Manusia Perguruan Tinggi Pendekatan Budaya Kerja Dosen Profesional Panduan Praktis Manajer Pendidikan Tinggi Berbasis Riset. Ideas Publishing. Beheshfiar, Malikeh \& Safarian, M. (2013). Human Resource Maintenance: A Vial Factor to Promote 
INTERNATIONAL JOURNAL OF ACADEMIC RESEARCH IN BUSINESS AND SOCIAL SCIENCES

Vol. 11, No. 1, 2021, E-ISSN: 2222-6990 @ 2021 HRMARS

Job Commitment. International Journal of Academic Research in Business Administration and Social, 3(2).

Beheshtifar, M., \& Asadi, H. (2013). A Study of Human Resources System and Employees Respond to Customers. Asian Journal Research in Banking and Finance, 3(12).

Chikari, G., Rudhumbu, N., \& Svotwa, D. (2015). Institutional Continuous Professional Development as a Tool for Improving Lecturer Performance in Private Higher Education Institutes in Botswana. International Journal of Higher Education Management (IJHEM), 2(1), 26-39.

Knight, J. (2006). Higher Education Crossing Borders: A Guide to The Implication of The General Agreement on Trade Services (GATS) for Cross-border Education. UNESCO Publisher.

PB, T. (2010). Manajemen Sumber Daya Manusia Perspektif Partnership dan Kolektivitas. Oryza. Wibowo. (2013). Manajemen Kinerja. PT. RajaGrafinda Persada. 